Human resource management standardisation and adaptation in franchises

Ashlea Kellner

Centre for Work, Organisation and Wellbeing, Griffith University, Brisbane, Australia

Email: $\quad$ a.kellner@griffith.edu.au

Tel: $\quad+61408836634$

Mail: $\quad 170$ Kessels Road, Nathan Queensland, Australia, 4111 


\section{Human resource management standardisation and adaptation in franchises}

Franchising is synonymous with standardisation and control, to achieve system-wide efficiencies and consistency in the brand image. Scholarly literature on human resource management (HRM) in this context has, to date, been relatively one-dimensional, discussing standardisation of HRM from the franchisor's perspective with insufficient consideration of the role and experiences of franchisees. This article seeks to extend the concept of core and peripheral franchising components to HRM activities, presenting findings from a three-case study of Australian coffee franchises. The findings suggest reframing HRM in franchises as two separate but potentially overlapping systems managed by franchisor and franchisee, with core and peripheral elements that may or may not align. Subsequent outcomes of misalignment for the franchise relationship are considered, and resulting franchisee HRM behaviours are illustrated in a Franchisee HRM Response Matrix.

Keywords: Human resource management, franchise, standardize, franchise relationship 
The franchising business model has experienced remarkable and rapid success across industries and internationally. For the entrepreneurial 'franchisor' (system developer and owner), franchising enables a business to pursue growth, securing a portion of revenue from each business unit. For 'franchisees' (business unit owner-managers), franchising offers the benefits of entering an established business with developed systems and support, and a recognised brand. Franchising has seen huge success in the US market where the total number of units is nearing 800,000 (International Franchise Association, 2015). Australia is home to only one tenth the number of units, however the smaller market is more heavily saturated, with one of the highest per-capita rates in the world (Frazer, Weaven, \& Grace, 2014).

Business format franchises, which represent the majority of systems, standardise and control franchisees' business activities such as site selection, finance, supply relationships, marketing, pricing and training (Kaufmann \& Eroglu, 1998). The balance of corporate standardisation and local adaptation is a topic of ongoing academic discussion, however there has been limited application of this debate to the core business function of human resource management (HRM) (Grünhagen, Wollan, Dada, \& Watson, 2014; Truss, 2004). HRM encompasses practices, policies, processes and overarching philosophies that guide the management of employees, and the role of a strong HRM system in influencing organisational performance is well established (for further discussion see Boxall, 2012). Despite such evidence, study of HRM in franchises is undeveloped and fragmented, and limited in its consideration of franchisees' experiences (Kellner, Townsend, Wilkinson, \& Peetz, 2014; Truss, 2004). 'Micro-level studies focused at the franchisee and unit levels are sorely needed... to improve understanding of franchise human resource practices' (Castrogiovanni \& Kidwell, 2010: 234).

Kaufman and Eroglu's (1998) core- periphery model is useful to illustrate how particular activities, including HRM, are centralised and standardised according to the franchisor's perspective. Their article, and research that has followed, however, has not adequately considered inconsistencies in how core and peripheral elements may be conceptualised by the franchisee. In this article, the core-periphery model is adapted to account for differences in the interests and expectations of franchisor and franchisee, and to illustrate the degree of alignment in corporate governance between parties. 'Misaligned governance' is a common characteristic of alliances that fail to satisfy partner expectations, and it has been linked to a range of negative performance outcomes (Nickerson \& Silverman, 2003; Sampson, 2004). Limited benefits - such as centralised services, policies and support in relation to costs of the relationship, can deteriorate franchisees' perception of the value 
offered to them by the franchise relationship (Harmon \& Griffiths, 2008). Hence, this article aims to develop a more nuanced understanding not only of HRM system governance and alignment, but of how franchisees' experience it; how it can shape perceived relationship value; and the ways in which franchisees respond to it through their HRM behaviours.

This article examines the results of a 'micro-level' case study of three fully-franchised Australian cafe chains. The following discussion of standardisation and adaptation leads into a review of the relevant literature on HRM in franchises, and to the research question and subquestions. Details of the research methods are followed by the findings, which illustrate weak and strong HRM alignment across the cases; subsequent outcomes for perceived relationship value; and four associated franchisee behaviours which are captured in the HRM response matrix. The article concludes with a discussion of practical and theoretical implications, limitations and directions for future research.

\section{Standardisation versus local adaptation}

Consistency and control via standardisation comprise the foundations of the franchise model (Cox \& Mason, 2007). Standardisation of business functions such as marketing or supply chain management can benefit the franchise system through cost efficiencies, quality control and uniformity of the brand image (Cox \& Mason, 2007; Kaufmann \& Eroglu, 1998). Despite the centrality of standardisation to the franchise model, not all business activities can or should be controlled by the franchisor. Geographical dispersion on a local, domestic or even international level can mean franchisee knowledge of home market and resource conditions is often superior to the franchisor's (Doherty, 2007). Hence, local adaptation in some aspects of business can benefit the franchise (Kaufmann \& Eroglu, 1998). At the extreme, strict standardisation can be detrimental in discouraging entrepreneurial franchisee behaviour such as product innovation or solutions that can add value to the whole network (Phan, Butler, \& Lee, 1996), and may lead to dissent and deviant or rebellious franchisee behaviours (Baucus, Baucus, \& Human, 1996). Balance is key, between activities that are controlled, centralised and standardised (terms used interchangeably herein), and those which are de-centralised, adapted and managed more autonomously by franchisees (Grünhagen et al., 2014; Kaufmann \& Eroglu, 1998; Kellner et al., 2014).

Kaufman and Eroglu (1998) offer a conceptual framework to understand this balance of standardisation and adaptation in the franchise model. The authors suggest activities central to the brand and reputation are deemed 'core' and subject to system-wide standardisation, while 
less critical 'peripheral' activities are permitted unit-level adaptation. Each franchise will define components differently, however, core elements in a high-end boutique coffee franchise may include coffee quality and professional barista training, while staff uniforms and parking arrangements may be peripheral and subject to variation between units (for more detailed discussion, see Kaufmann \& Eroglu, 1998, pp. 78-82). This concept is illustrated in Figure 1.

\section{[INSERT FIGURE 1 AROUND HERE]}

Implementation of standardised policy or processes will be influenced by franchisee motivations, for instance, to adapt a standardised menu to increase profits. The franchisee may work collaboratively with the franchisor to develop new menu items to suit local customer preferences, or they may act opportunistically, substituting lower cost ingredients or failing to offer key menu items. Adaptation may benefit the brand, however when it distorts or confuses the customers' perception of the brand, it should be restricted (Kaufmann \& Eroglu, 1998).

The motivation of a franchisee to act opportunistically or withhold effort can be better understood by considering the interests of both parties to the relationship. The franchisor aims for maximisation of franchisee turnover (as their profits are typically a percentage of franchisee turnover) while maintaining brand equity (Dant \& Nasr, 1998; Felstead, 1991). However, 'an increase in turnover is neither a necessary nor a sufficient condition for an increase in franchisee profits' (Felstead, 1991:46). Therefore, a situation arises where the franchisee is more interested in increasing profits than sales turnover, and may have limited interest in protecting the brand.

\section{Aligning core and peripheral interests}

Considering the potential for conflicting interests outlined by agency theory (Cochet, Dormann, \& Ehrmann, 2008), Kaufmann and Eroglu's (1998) model does not account for differences in opinion regarding what is (or should be) core and peripheral elements in the franchise relationship. A standardised employee performance management process may be deemed critical by the franchisor, while franchisees see benefits of adaptation to suit individual management style and would prefer it were peripheral. Close alignment of franchisor and franchisee expectations around the core and peripheral HRM activities would benefit the brand and franchise relationship, while poor alignment could lead to conflict and 
damage performance. If we apply this concept to the previous model, we could illustrate overlap of both parties' core and peripheral activities as shown in Figure 2.

\section{[INSERT FIGURE 2 AROUND HERE]}

Figure 2 provides a simple representation of the degree of alignment between franchisor and franchisee by the level of overlap of the two spheres; no overlap indicates no alignment; some overlap such as in Figure 2 indicates weak alignment; and where the two spheres overlap and all or most core and peripheral activities are in the centre of the diagram, this is strong alignment. While perfect alignment of interests is desirable, it is unlikely (Pizanti \& Lerner, 2003), and we are more likely to find balance somewhere in-between. This model will be adopted in the findings to illustrate the degree of alignment between franchisor and franchisees’ perceived core and peripheral HRM processes and policies.

The degree of alignment of expectations in the franchise relationship is important, as misalignment can result in negative consequences for both parties. In the broader context of collaborative ventures, for example, there is a tendency for senior managers - 'after negotiating what capabilities each firm brings to the alliance - [to] leave further details unaddressed' (Sampson, 2004). Such failure to properly outline roles and responsibilities within a partnership has been linked to undesirable outcomes. Drawing on previous findings that suggest a large number of joint alliances fail to satisfy partner expectations, Sampson (2004) adds that weak and incomplete governance limits collaborative benefits. Other studies indicate organisations with inappropriate or misaligned governance are more likely to experience poor financial performance and increased organisational failure rates (Nickerson \& Silverman, 2003; Silverman, Nickerson, \& Freeman, 1997). Misalignment of expectations arising from poor governance will also have a clear link to franchisees' perceptions of the franchise relationship value, a point which is investigated further in this article. First, however, this concept of (mis)alignment between parties will be applied to HRM, a component of the business format poorly addressed in the franchise agreement and associated corporate governance mechanisms (Brand \& Croonen, 2010; Kellner et al., 2014).

\section{Alignment of HRM in franchises}

Scholarly investigation of HRM in the franchise context is restricted to a handful or papers, which, on the whole, indicate HRM is deemed a peripheral business function (Brand \& Croonen, 2010; Grünhagen et al., 2014; Kellner, Peetz, Townsend, \& Wilkinson, 2015; 
Truss, 2004). There is of course differences between HR practices, some of which appear to be deemed more pertinent to the brand and therefore subject to greater standardisation. Some studies suggest employee training practices are subject to standardisation (Doherty, 2007; Paik \& Choi, 2007) although this may only apply to training for employee brand awareness rather than career or skill development (Truss, 2004). Similarly, compliance with employment legislation is typically a standard contract term (Brand \& Croonen, 2010), and given the threat of reputational damage arising from non-compliance, franchisees are required to follow standardised procedure in this regard (Kellner et al., 2015). Allocation of decision rights to franchisees for other aspects of HRM however - such as recruitment or performance management - has been subject to very little academic discussion.

Limited franchisor involvement in franchisees’ management of human resources could arguably benefit both parties. In a large single case study, Brand and Croonen (2010) find small franchised units outperform larger and corporate owned units in HRM, exhibiting greater effort, motivation and local adaptation. The authors suggest franchised units perform better than corporate units which were subject to greater bureaucratisation and centralisation of HRM. Similarly, Grünhagen et al. (2014) argue franchisee operational autonomy in HRM positively moderates the relationship between performance and entrepreneurial orientation, proposing a 'weaker centralized HR function from the franchisor allows for an entrepreneurial climate that encourages each business unit to be innovative in their development of HR practices' (p. 832).

It is clear even from limited research that strict standardisation of the entire HR function is almost assured to result in negative consequences for both parties to the franchise relationship, and there are shared benefits of ensuring a degree of operational autonomy. What has been overlooked somewhat in such literature, and is developed in greater depth in this article, is a more nuanced classification of HRM standardisation in franchises - precisely what degree of HRM autonomy is permitted, and in which aspects of HRM practice. This delicate balance between autonomy and centralisation of HRM is determined by consideration of the costs and risks associated with controlling these practices for the franchisor (Kellner et al., 2014). Liability is a prominent risk, and it can work in two directions. On one hand, where a franchisor exerts high control by dictating to franchisees, they risk liability if information provided is inaccurate (e.g. incorrect employment termination procedures). On the other hand, where the franchisor exerts little control, franchisees may engage in opportunistic behaviour (e.g. underpayment of staff), for which the franchisor may be found liable. Such liability is not inherent in all countries, however high profile employee underpayment and associated 
exploitative practices by 7-Eleven franchisees in Australia has seen such policy proposed to hold franchisors accountable for breaches of employment legislation made by franchisees (see 'The Coalition's Policy to Protect Vulnerable Workers', Liberal Party of Australia, 2016).

For the franchisor, determining 'high risk core' and 'low risk peripheral' HRM activities is complex. The benefit of high control through standardisation is to limit liability, and arguably more importantly, to protect the brand from reputational damage. Conversely, standardisation incurs a cost, and intensive monitoring of managerial activity goes against a basic premise of franchising to limit involvement of the franchisor in running the franchisees' business. While there is certainly a case for less standardisation (Brand \& Croonen, 2010; Grünhagen et al., 2014), there are also disadvantages of complete decentralisation that have the potential to damage performance (Truss, 2004) or destroy the brand (Kellner et al., 2015).

A final layer of complexity which is undeveloped in the extant research is the voice and perspective of franchisees. With the exception of Truss (2004), there has been little consideration given to how the franchisor's HRM system is interpreted and implemented at the franchisee level. Given the inherent differences in franchisee and franchisor interests (Pizanti \& Lerner, 2003), and ambiguity in the franchise agreement regarding HRM, we can assume inconsistencies are likely to exist regarding which practices should be standardised or permitted adaptation. This is important, as noted, as such misalignment in the expectations of franchisor and franchisee can be negatively related to performance (Nickerson \& Silverman, 2003; Sampson, 2004). Accordingly, this study aims to identify and contrast core and peripheral HRM activities from the perspective of the franchisor and franchisee, asking the overarching research question:

What is the degree of alignment of core and peripheral human resource management practices in the franchise relationship?

\section{The franchise relationship}

Where governance is unclear, inadequate, weak or non-existent, the resulting negative outcomes may be better understood by considering the franchisees perception of value to be gained by involvement in the franchise relationship. A strong or weak alignment will undoubtedly shape franchisees' perceptions of value gained from the franchisor, and influence the way they manage human resources. In a conceptual paper, Harmon and Griffiths (2008) propose franchisees' perceived relationship value is a trade-off between the benefits of the relationship and the tangible and intangible costs. Benefits can include centralised services 
and support, availability and risk reduction, while costs include direct expenses, time, resources and conflict. According to the authors, perceived relationship quality (a measure of satisfaction, trust and commitment) shapes franchisees' perceived relationship benefits and therefore, relationship value. Hence in a high quality relationship, where the franchisee feels supported and believes the franchisor is honest and concerned with their best interests, the relationship will be perceived as more valuable.

Positive relationship value can manifest increased financial performance, innovation and desirable behaviours such as satisfaction, loyalty, knowledge sharing, and innovation, while negative relationship value can result in opportunistic behaviour, shirking responsibilities, conflict and dissolution of the partnership (Cochet et al., 2008; Davies, Lassar, Manolis, Prince, \& Winsor, 2011; Harmon \& Griffiths, 2008). Through this lens, franchisee autonomy in the context of positive perceived relationship value may benefit the brand through 'creation of new strategies and new solutions to existing problems' (Phan et al., 1996: 382). Conversely, franchisees that are dissatisfied, mistrusting and uncommitted to the relationship could struggle under time and resource pressure, unlikely perform well, cooperate, innovate, or make improvements.

The focus of this paper is HRM alignment in the franchise relationship. Relationship quality and value add another dimension to help understand the human context in which HRM occurs, and explain implications of franchisee responses later detailed in the Franchisee HRM response matrix. Accordingly, this article asks the following additional sub-questions:

1. How does alignment of the core-periphery model of human resource management influence the franchisees’ perceived relationship value?

2. How does alignment of the core-periphery model of human resource management influence franchisees' responses to managing people?

\section{Methods}

Given limitations of prior research, immersion and intensive study of a small number of cases is highly suitable (Denzin \& Lincoln, 2000; Yin, 2009). An inductive, qualitative case study design was adopted to obtain rich and contextualised data providing theoretical insight into the research problem (Eisenhardt, 1989). While generalisability of case research is often criticised due to use of small samples and 'critical, unique or revelatory cases', this study attempts to increase relevance of the findings for other franchises (at least in the same 
industry sector) through selection of three 'representative or typical' cases (Yin, 2009) from the heavily franchised Australian food and beverage services industry.

The cases in this study are Australian-owned, mature (20-30 years), operate the majority of stores in the domestic market, and are almost fully-franchised (two or less corporate units each). A fully or near-fully franchised governance structure is typical for Australian franchises, where over one third hold no corporate units, and majority hold less than two (Frazer et al., 2014). They are competing cafe-style business units that typically employ 10-30 employees on various types of contract (full/part time and casual). Franchise fees payable by franchisee to franchisor were set at six percent of sales in all cases at the time of research. While all technically 'large' franchise systems (Frazer et al., 2014), the total number of units varied between cases. Cases are given pseudonyms reflecting size relative to one another: 'Short Black' (100 units), 'Cappuccino' (300 units) and 'Cafe Latte' (1000 units). More details on each system and interviews are provided in Table 1.

\section{[INSERT TABLE 1 AROUND HERE]}

Data collection began in 2011, and collection and analysis was completed by 2013. The primary data source were semi-structured interviews, although the researcher also communicated frequently with key contact persons, attended informal meetings, participated in HRM-related workshops, and gathered documentary evidence of strategy, policies and procedures. Access was granted via the most senior HR manager in each organisation. A purposeful sampling method was adopted for corporate interviews, whereby employees were invited to participate based on potential knowledge on the area of investigation. Interviews were conducted with representatives from HR and training departments (which in all cases operated separately) and role titles of interviewees are provided in Appendix 1. Franchisees were selected by the contact person to represent different levels of tenure (very new and long established franchisees) and unit ownership (single and multiple unit owners). While there is a possibility that the primary contact only suggested interviewees who would portray the organisation favourably, such an approach would be of no benefit (as research outputs were de-identified).

Thirty-seven interviews were conducted and electronically recorded, each averaging one hour. Five were repeat interviews, conducted when further investigation was required. While data from all interviews inform the findings presented here, quotes are drawn only from the twenty franchisee participants, reflecting the focus of the article. 
The interview protocol was first refined among nine additional interviewees in a pilot. A semi-structured approach was deemed most suitable to create an atmosphere of informal discussion and produce an accurate understanding of franchisees' perspectives (Cassell, 2009). Interview transcripts and field notes were analysed alongside secondary documents to demarcate core and peripheral activities for franchisees (core and peripheral activities for franchisors were identified earlier and reported on in Kellner et al., 2014). There were minor variations between franchisees' determination of core and peripheral activities, however the findings reported here are representative of the vast majority in all cases.

Interview data were analysed using a two-step coding procedure based on the inductive analysis' technique (Patton, 2002) of reading and re-reading data, assigning keywords (second-order categories) to passages of text, sorting and identifying emerging themes (firstorder categories). A process of creating, deleting, merging and dividing categories was conducted among a team of researchers with the aim of reducing bias and improving reliability (see for example, Kreiner, Hollensbe, \& Sheep, 2009). This process resulted in two key themes and six sub-categories: the first theme concerned franchisees' perspectives of the franchise relationship pertaining to HRM (positive and negative) and the second theme related to franchisees' responses to standardisation (adopt, adjust, acquire and add). Findings presented here are a result of consideration and analysis of each category of data.

\section{Unpacking the HRM system}

Through interviews with corporate employees and analysis of policy documentation, the study first established cases had unique HRM systems (detailed in Table 2) resulting from contrasting structures and roles of the HR department: the Cafe Latte HR department serviced corporate employees only; the Short Black HR department existed in a shared service framework also supporting three additional franchise systems; Cappuccino's HR department consisted of a HR Manager and Advisor who proactively supported franchise units.

A formal, written HR strategy was sighted at Cappuccino, which had been developed in conjunction with organisational-level strategy. While a rough, informal departmental plan was sighted at Short Black, a strategy did not exist in any format at Cafe Latte. Policies, procedures and templates on all aspects of people management were available to franchisees at Cappuccino, while these were far less developed at Short Black and Cafe Latte. As the HR department did not interact with Cafe Latte franchisees, there were no communication mechanisms in place. Communication was typically one way at Short Black, while multiple 
mechanisms existed at Cappuccino including newsletters, focus groups, conferences, email and phone.

Franchisees in all chains completed formal (classroom-style) and informal (store-based) training inductions. The HRM component was limited to a four hour overview at Cafe Latte, and two days in the other chains. While the content at Short Black was very practical (e.g. rostering and administering pay), Cappuccino provided a more holistic and theoretical view of the employment process (e.g. organisational culture and improving retention). Mode of delivery for employee training varied, however in all chains was at least partially standardised. Employment relations support was provided at Cappuccino and available through an external agency at Short Black (at franchisee's expense). On-going training in HRM for franchisees and store managers was only provided at Cappuccino, who also conducted a quarterly 300 item assessment on all aspects of business management (including 30 measurable HRM items) and rewarded and recognised high performing franchisees at their annual conference.

\section{[INSERT TABLE 2 AROUND HERE]}

In summarising Table 2, it is clear the franchisors demonstrated varying levels of standardisation of the HRM system as a whole: low at Cafe Latte and Short Black; and comparatively higher at Cappuccino. As previous studies have suggested, training was subject to greater standardisation in all cases compared to other HRM activities, due to its pertinence to the brand (Doherty, 2007; Paik \& Choi, 2007; Quinn \& Doherty, 2000; Truss, 2004). A detailed analysis of the franchisor's standardised HRM activities is provided in an earlier article (Kellner et al., 2014), and the following section will present activities deemed core and peripheral from the franchisees’ perspective, resulting in a strong alignment at Cappuccino and a weaker alignment at Short Black and Cafe Latte.

\section{Strong core-peripheral alignment}

Alignment between the franchisor and franchisees' core and peripheral HRM policy and process was strongest at Cappuccino, as illustrated in Figure 3. Strong alignment is indicated by all or the majority of HRM policies, practices and processes of the system being deemed core or peripheral simultaneously by franchisor and franchisees, indicating strong agreement about what should be standardised and adapted. 
A centralised portal on the website to advertise positions and receive applications from job applicants was deemed core by franchisees and provided by Cappuccino. Franchisees viewed selection as a peripheral activity where they preferred to follow their own tailored approach, and Cappuccino provided basic guideline materials (e.g. interview questions, reference check guidelines, welcome packs).

\section{[INSERT FIGURE 3 AROUND HERE]}

Almost unanimously, between new and well-established franchisees, employment relations processes were deemed pertinent, complex and fundamentally core. Processes such as wage determination, dispute resolution and termination were viewed by franchisees as critical to effective functioning of the business and centralisation of processes and support services was requested and provided. Similarly, the centralised franchisee induction to HRM and associated ongoing training were valued by franchisees as core activities that delivered valuable management skills and knowledge. Employee training in product and service delivery - particularly the induction - was heavily standardised, consistent with franchisees' perception that such training was integral to ensure employee understanding of key aspects of the brand.

Core activities, shown in Figure 3 in the centre of the aligned circles, were deemed by both parties as more efficient and cost effective to centralise and standardise, and did not benefit from a high degree of local adaptation. Cappuccino controlled the franchisee induction and training, and online employee training program, via the corporate office, and closely monitored attendance and completion rates. Consistent use of the recruitment portal was audited online, and employment relations was monitored through regular store assessments (noted in Table 2), and scheduled visits from a corporate franchise consultant. Employment relations, in particular, was closely scrutinised, and misconduct - intentional or unintentional - was identified and managed with involvement of the corporate industrial relations advisor (for more detailed discussion of franchisor control over employment in this context, see Kellner et al., 2015).

Performance management, incentive and reward, activities depicted outside the core of the circles but still aligned centrally, were seen as less fundamental to business functioning and more effectively locally managed. Accordingly, while advice and support were made available, the franchisor chose not to standardise or control these peripheral activities. 
The strong core-periphery alignment identified at Cappuccino appeared to positively influence quality and perceived value of the franchise relationship for franchisees. Although key measures of relationship quality were not directly measured, interviewees expressed satisfaction with the franchisor relating to HRM interaction, and trusted the franchisor to provide sound guidance and support. Franchisees were satisfied with the level of standardisation and agreed that key benefits were time and cost savings. Franchisees were not required to invest time or resources researching and developing HRM policies and procedures, rather, they could adopt or adjust those provided by the franchisor. In turn, this allowed franchisees to focus on improving other aspects of business:

Cappuccino has a corporate CD and it has a lot of standard procedures that you can use. I have found that fantastic. I can look on it and it has interview prompt sheets for asking questions, reference checks. I use a lot of their corporate things. They've done the major part of the thinking for me. So it gives me time to concentrate on the store a lot more now too.

Franchisee 4, Cappuccino

Additional to these advantages, franchisees - particularly those with less experience or new to the system - indicated standardisation reduced the likelihood of unintentional noncompliance with legislative requirements:

They've given me the set up. I had no idea of the setup, the HR and the wages. Maybe I could have learned it but would I have made lots of mistakes along the way? Probably. Would I have been successful? I don't know. Franchisee 2, Cappuccino

The relationship between the HR department and franchisees in this case was characterised by two-way communication, collaboration, involvement and responsiveness, developing commitment between both parties. The suite of support provided to franchisees resulted in a situation of high positive perceived relationship value, where HRM benefits of the relationship outweighed the costs. While the study did not examine financial performance outcomes, the result of strong alignment at Cappuccino was legal compliance, consistent high quality HRM practice, brand protection, and as will be discussed further on, knowledge transfer and improvement of the HRM system.

\section{Weak core-peripheral alignment}

The core-periphery alignment between franchisors and franchisees in the other cases showed less overlap. Weak alignment is indicated by few HRM policies, practices and 
processes of the system being deemed core or peripheral simultaneously by franchisor and franchisees, indicating poor agreement about what should be standardised and adapted. As Cafe Latte and Short Black exhibited almost identical levels core-periphery alignment, these have been illustrated jointly in a single diagram, shown in Figure 4.

\section{[INSERT FIGURE 4 AROUND HERE]}

In these two cases, standardisation of HRM was generally much lower than Cappuccino, although peripheral elements aligned between franchisor and franchisee were identical in all cases. The franchisee induction, including discussion of HRM, was viewed as important by franchisees and franchisors alike, and hence was standardised, although the breadth of HRM content at Cafe Latte was barely satisfactory to franchisees. Again, employee training was deemed core and centralised, with both cases offering sophisticated online portals for employee induction and ongoing basic training.

The point of interest lies in the activities that are not in the centre of the diagram - those which are not aligned - about which franchisor and franchisee disagree regarding standardisation. First and foremost, employment relations policy, procedures and general support were not provided directly by the HR department in either case. This was a point of contention and dissatisfaction for franchisees that represented a tangible cost of the relationship. Likewise, a centralised recruitment portal was not available to franchisees in these cases, leaving each franchisee to adapt their own process, failing to realise efficiencies available through a more standardised process. Finally, franchisees noted ongoing training in employment or HRM topics was desirable and important (core), while this was seen as peripheral by the franchisor and not provided by either case. A summary of this weak alignment is provided by the following franchisees from each case:

To be very honest, on the staffing level, HR and all of that, they don't provide a whole lot of help... They can give you general guidelines. Like how to train staff to do kitchen or coffee, on the job skills training. But in terms of staff management, you're pretty much left out on your own. They are your staff and you have to handle them... So in that sense it's kind of hard.

Franchisee 1,

\section{Short Black}

I think the support is really good. The only thing that could be improved is in the HR area... I think they probably need to take a bigger role in that aspect of business, like 
making sure people are getting paid the right money. From what I can see is they will do everything else but leave that part of it up to you.

As the second quote indicates, these franchises did not universally adopt a 'hands off' approach to supporting franchisees, rather, involvement was limited in HRM compared to other areas such as operations or finances (for further discussion see Kellner et al., 2015). These quotes give a sense of the relationship quality evident at Cafe Latte and Short Black. Franchisee perspectives of the franchisor regarding HRM were generally negative and there was a consistent acknowledgement that guidance provided was inadequate, creating a challenging situation for franchisees.

While the HRM benefits provided to franchisees were limited, tangible and intangible costs were high. The franchisor's position on standardising HRM in these two cases left franchisees in a position where they needed to seek and often pay for support independently, for example from 'my accountant' (Franchisee 6, Short Black), 'Fair Work Australia' (Franchisee 3, Cafe Latte, referring to a government-run industrial relations institution), and ‘employer associations’ (Franchisee 6, Cafe Latte). Where franchisees could not afford to pay for advice and support, there was still the less tangible cost to their own time and resources in gaining information they required.

In these two cases, there was a misalignment in expectations and reality of support, resulting in a feeling of dissatisfaction expressed by interviewees:

I suppose initially we were pretty shocked. They didn't offer much [HR support] at all. This is my first time in franchising and I thought it would be more laid out, more of an implementation of a pre-existing system. I was quite surprised that not much existed.

Franchisee 1, Cafe Latte

As a person going into a franchise, that's the sort of support I was wanting, and it's not there. I don't know how far other franchises go, but it was my perception that all those sort of employment-related statutory and structural things would be there for you... That sort of stuff is probably what I expected at the start.

\section{Franchisee 6, Short Black}

Similar to the proposition by Harmon and Griffiths (2008), there appears to be a negative relationship between franchisee relationship value and franchisee satisfaction. Other proposed behavioural outcomes such as opportunism and shirking (Harmon \& Griffiths, 
2008), while difficult to gauge from franchisee interviews, were noted by corporate interviewees in these cases (e.g. underpayment or cash payment of employees, failure to complete mandatory employee online training). In sum, the strategy of the franchisor was to avoid costs and risks associated with standardisation, in contrast to the proactive brand protection approach evident at Cappuccino (a more detailed analysis of the impetus for the franchisor's strategy is provided in Kellner et al., 2014). This resulted in a weak coreperiphery alignment, and ultimately, negative consequences associated with low perceived relationship value.

\section{Franchisee responses: Adopt, adjust, acquire or add}

Within the parameters of standardisation and adaptation, and in the context of variations in perceived relationship value, there are a number of different ways franchisees can manage human resources. Cross-comparison between the franchisor and franchisees' policies and processes for specific HRM activities suggested franchisee HRM behaviour could be captured in four categories: adopt the franchisor's recommended HRM policies and procedures; adjust the franchisor's policies; acquire policy from another source; or add through creation of new policy. The behaviours are shown in a matrix in Figure 5, varying according to the level of HRM standardisation and the degree of franchisees’ local adaptation.

\section{[INSERT FIGURE 5 AROUND HERE]}

Where robust, comprehensive and reliable standardised resources were available to franchisees these were generally adopted. Paperwork and templates - such as employee induction kits, misconduct warning letters, job advertisement outlines or job descriptions were readily accepted and adopted by franchisees in all cases. Such resources were administrative or regulative employment-related policies and processes that did not benefit from alteration by franchisees in the context of a fairly non-strategic work environment. The franchisees' HR training and induction were adopted, and input into these processes was generally not encouraged by the franchisor. Elements of corporate employee training programs tended to be adopted (e.g. online inductions and training), although the hands-on practical components were not. Opportunity for franchisees to adopt was greatest at Cappuccino where HRM policies and processes were more developed, while at Cafe Latte and Short Black to adopt was not always an option. Overall, where policy and processes were 
deemed core by both franchisor and franchisee, adoption of at least some of these resources was most likely to occur.

Many franchisees chose to adjust some of the franchisor's standardised policies and processes. This was evidenced in more practical aspects of management - such as in store training - and adjustments were made according to the franchisee's situation, previous experience or preferred management style. Franchisees at Cappuccino adjusted the franchisor's approach to suit their own requirements (and were often encouraged by the franchisor), particularly in employee induction and training, and some more experienced franchisees adjusted recruitment policy and procedures:

The [HR] manual... It was mainly about hiring staff, how to place ads, the correct wording for things. It had position descriptions, it had some training schedules in it, but once again we didn't like it all so we changed it. Franchisee 6, Cappuccino

In theory, corporate office has an [employee] induction checklist ... it is usually about a two hour process... Unfortunately, because most people who start don't last, you don't end up doing the inductions for every person initially... once a person seems like they are gonna make it and be a part of the team on-going, then you'll have the induction, the formal induction.

Franchisee

\section{5, Cappuccino}

Adjustment occurred in core areas where standardised resources existed and but there was an incentive (particularly by more experienced or tenured franchisees) to adapt locally. Positive relationship value relating to HRM at Cappuccino resulted from strong HRM alignment (and hence, high perceived HRM benefits and a quality relationship characterised by satisfaction, trust and commitment (Harmon \& Griffiths, 2008). In this climate, collaboration, communication and knowledge transfer between parties was evident (Gorovaia \& Windsperger, 2013). As Franchisee 1 at Cappuccino explains, 'We lead the way for a lot of other franchisees. We'll come up with an innovative idea and they'll install it in other stores.' The franchisor was receptive to franchisees' ideas for improvement to HRM and this was particularly evident in training practice. As the following franchisees elaborate:

With the franchisee in-store training we saw a shortfall straight away. So we said, 'We can help you deliver better training...' We've tailored the training to meet some of the things we saw. Operationally, 80 percent of the franchisees that come in have no hospitality experience. So we needed to tailor our training in that way... [The HR 
Manager] is great. She comes and asks for my advice, we sit down and think of different ways of approaching things.

Franchisee

6 ,

\section{Cappuccino}

Corporate office has been very happy with our performance, our people skills, the training we are putting in and the way we represent the brand... They now give us calls to go as 'Guest Trainers' to new franchises.

Franchisee

3,

\section{Cappuccino}

When the franchisor deemed an activity peripheral and no standardisation was evident, franchisees tended to acquire or add. With significantly less or no standardisation of a range of HRM activities at Cafe Latte and Short Black, such responses to managing HR were more prevalent. Policy or processes were acquired by franchisees from another workplace or context. For instance, one franchisee implemented selection techniques borrowed from the airline industry, where employee communication skills and presentation are highly valued.

The second interview is straight out of the Virgin Blue handbook. It's 'bring your talent and entertain us' ... communicate something you're passionate about, something you can engage me about. We have people singing, dancing, bringing YouTube videos, their favourite recipe. They've cooked up all sorts of crazy and wonderful things.

Franchisee

\section{1, Cafe Latte}

Another franchisee was completely transparent with financial turnover information in attempt to motivate employees and improve performance. This approach was borrowed from the franchisees' experience in sales-oriented work:

We have implemented things from the beginning ourselves. This is our roster, but the guys always know what our sales targets are for that day. It's written here on the roster, we are quite open... Whenever we hit targets for that day at the end of the week we give them a little scratchie or lottery ticket in their pay.

\section{Franchisee 6, Short Black}

Franchisees were more likely to acquire policy or processes at Short Black and Cafe Latte where there was far less standardisation overall, combined with a lower quality relationship. In these cases, franchisees could not trust or rely on franchisor support, nor was creativity or collaboration in HRM encouraged. To acquire is a logical strategy in areas the 
franchisee deems should be core but are not standardised, such as employment relations and parts of recruitment, that are legislated and complex and do not benefit from adaptation. It is a safer and simpler option to acquire employment policy or processes from an established organisation, for example, than to attempt to design or 'add' them yourself. Cappuccino franchisees tended not to acquire, as even in areas deemed peripheral by all cases such as performance management, basic guidelines and support were available.

The franchisor's peripheral activities - performance management and staff incentive and reward - were permitted complete local adaptation in all cases, resulting in very high variability of practice within cases. This variability can be attributed more to an add strategy at Cappuccino, and an acquire strategy in the other two cases. For example, Cappuccino Franchisee 1 developed his own formalised incentive and reward scheme: 'Team Member of the Year gets presented at the Christmas party. They get a trophy, a weekend away, breakfast, and an [accommodation] package.' Within the same organisation, Franchisee 2 rewarded staff linked to sales of a monthly promotion item: 'We do a promotion each month on one product and whoever wins that gets some cash.' Sales-based promotions and costly rewards such as these are unusual in such food services businesses, where staff are mostly casualised and turnover is high.

Evidence of innovation was limited in the other two cases, and more likely to fit into the category of 'acquire' as processes were typical in the industry. For instance, Short Black franchisees commented: 'All our staff are entitled to free hot beverages... We have food at half price for their lunches (Franchisee 4), and 'I give them above award wages...' (Franchisee 4). Similar feedback was obtained at Cafe Latte, where some franchisees were running a coffee art competition (an approach borrowed from another international chain), while others noted they 'haven’t done anything lately' (Franchisee 6). To add new policy in these cases was perhaps less prevalent because of the franchise relationship, where adaptation and collaboration was not openly encouraged, and innovation in HRM was not acknowledged, shared or rewarded.

Some comparisons can be made between single and multi-unit franchisees in these cases which contrast slightly with broader observations made hereto. Where franchisees had acquired two or three units, there was a need to employ an additional layer of management and some had the capacity to develop their own independent HRM processes, such as training and induction programs. As Franchisee 3 from Cafe Latte explained: 'Our induction program is really quite prescribed and defined. We have a training operations manager internally who oversees the co-ordination of that.' This arrangement was not typical, although it was evident 
at least in initial stages among some of the multi-unit franchisees interviewed. Multi-unit operations, as they expand, can become a medium to large business operating within the franchise structure, and begin to operate accordingly. While the complexities of this arrangement are beyond the scope of this study, it is apparent multi-unit operators tend to demonstrate a greater degree of local HRM adaptation compared to single unit franchisees, due to increased access to resources and time, and ability to achieve economies of scale through investment in some HRM processes.

The Franchisee HRM response matrix provides a framework to assist understanding of how HRM standardisation and adaptation can influence franchisee HRM behaviour. Adoption of corporate policy may be a satisfactory response when centralised policy is comprehensive and the practice area is one that benefits from standardisation - such as training (Doherty, 2007; Paik \& Choi, 2007) or employment relations (Kellner et al., 2015), and when both parties agree it should be core. When there is franchisee benefit in modifying standardised policy or process, the response will likely be to adjust.

Adjustment may occur when the franchisee deems an activity peripheral, such as franchisees altered some of the practical in store training technique, or other standardised policy that was not robust or complete. Where the intention of corporate policy remains the same or is improved, to adjust can benefit the system, but only if it occurs in the context of high franchise relationship quality. Where adjustment detracts from policy it may cause perceptible inconsistency between employees (e.g. 'why is an employee in a nearby store provided more comprehensive training?') and indirectly affect customers (e.g. employees display varied discretionary effort or customer service skills).

To acquire or add appear to be strategies implemented when the franchisor deems an activity peripheral, but the franchisee deems it core or peripheral. Where a majority of franchisees acquire policy from outside the system this may indicate serious misalignment, where an urgent need for support is unfulfilled. In such a scenario, to add may also be a dangerous response, driven by franchisee self-interest and opportunism. Although in this study, in the context of a positive relationship at Cappuccino, the add response had the potential to benefit the system as innovations were encouraged, recognised and shared. In sum, there is no optimal franchisee response, and each behaviour must be considered in the context of the perceived franchise relationship quality.

\section{Discussion}


Research at the intersection of franchising and HRM is has been slowly gaining ground over the last few years (Brand \& Croonen, 2010; Grünhagen et al., 2014). This article extends existing knowledge, and adds some original contributions of its own. The finer detail of HR practice in franchises has been illustrated, depicting franchisee perceptions and experiences, and categorising their behavioural responses. More importantly, these findings shift us away from a one-dimensional analysis of HRM in the franchise relationship to a more holistic perspective that acknowledges the roles and inputs of both parties. Adapting the coreperiphery model (Kaufmann \& Eroglu, 1998) to illustrate HRM in the franchise relationship accounts for differences in interests and expectations and highlights areas of critical weakness and misalignment. The negative consequences of misaligned governance and poor perceived relationship value underscore the importance of this study, particularly from a practical standpoint. Implications pertaining to these issues will now be explored, concluding with a summary of study limitations and avenues for future research.

\section{Theoretical implications}

Applying and extending work by Kaufmann and Eroglu (1998) on standardisation and adaptation, this article reconceptualises HRM in franchises. Prior research has predominantly discussed HRM in franchises as a dichotomy of standardisation and adaptation prescribed by franchisors and applied by franchisees. Weak centralisation and control over HRM has linked to positive outcomes including unit performance (Brand \& Croonen, 2010), innovation and entrepreneurial behaviour (Grünhagen et al., 2014). This study did not directly seek to measure performance outcomes on any level, hence it does not directly contradict not support these findings. Rather, it suggests, the reality may be more complicated.

Enforcing strict control and standardisation can certainly be stifling and damaging to creativity and entrepreneurialism (Baucus et al., 1996; Cochet et al., 2008; Grünhagen et al., 2014), although excessive autonomy with no framework for guidance also appears detrimental. An ideal scenario, where both parties 'win', may look something like the approach evidenced by Cappuccino. The HRM arrangement in this case created advantages for both parties - not only via benefits to franchisee time, costs and accuracy - but through encouraging innovation and improvement to corporate policies and procedures. Knowledge sharing and communication around HRM at Cappuccino multi-directional, recognising potential for value to be added by franchisees (Baucus et al., 1996; Phan et al., 1996). The organisation centralised and standardised process-driven aspects of HRM, but encouraged compliance in a non-coercive way (noted by other authors such as Paik \& Choi, 2007; Quinn 
\& Doherty, 2000). Practices that benefitted from local adaptation, or where personal management style was pertinent, were permitted autonomy. But even in these peripheral areas, guidance was still available.

While not intending to undermine the debate over benefits of weaker or stronger HRM centralisation, the findings from this study emphasise the important argument for achieving alignment in the franchise relationship. The core-periphery model as adapted for this study illustrates how franchisor and franchisee can have contrasting perspectives and interests about the centrality of an activity to their business. Given the duality of ownership and influence, reframing HRM as two separate but potentially overlapping systems, with core and peripheral elements that may or may not be aligned, is a more representative conceptualisation. A franchisor may make the strategic decision to heavily centralise HRM or not - but what appears to be more important is that there is at least some alignment in what is considered core and peripheral by both parties.

\section{Practical implications}

The most important messages for practitioners and managers to take away from this study relate to the potential outcomes of misalignment for the franchise relationship, and how the franchisors' strategic decisions influence franchisee HRM behaviour. The strength of alignment reinforces franchisees' perception of relationship quality, which influences their determination of benefits and costs of the franchisors HRM support, ultimately shaping how much value they place on the relationship (Harmon \& Griffiths, 2008). The perceived HRM costs of the relationship at Cafe Latte and Short Black were greater than the perceived benefits, resulting in low relationship value. Arguably, this outcome was a result of poor governance in these cases - incomplete, inadequate, weak or non-existent discussion of people management systems and responsibilities in the franchise agreement and associated documents. A resulting misalignment - between governance expected by franchisees and that delivered by franchisors, reduced the perceived value of the relationship. The quality of the relationship deteriorated, characterised by mistrust and dissatisfaction.

This misalignment may have been caused by misinformation provided by the franchisor, or lack of discussion or clarification of expectations early in the franchise relationship. Franchisees are encouraged to question corporate HRM services, particularly in technical and arduous activities such as employment relations. Franchisors are urged to be explicit in outlining core and peripheral activities and associated support before agreements are signed, to avoid disappointment and damage to relationship value at a later time. Increased 
franchisor involvement, however, is not necessarily a straightforward solution. While franchisees expressed desire for greater standardisation and support, they may not be willing to pay higher fees to receive it. Corporate support is a service for which franchisees will inevitably be charged, and it must be noted initial establishment fees were highest at Cappuccino (although also notable - ongoing franchise fees in all cases were identical). If the franchisor increased standardisation and reduced autonomy - focussing instead on ensuring franchisee adherence to HRM policies and procedures - it is also unlikely franchisees would welcome such 'support'. A fulcrum point must exist - where compliance is optional and costs are at least hidden (built into the establishment or ongoing fees) - whereby franchisees will be most satisfied with franchisor involvement in HRM.

\section{Limitations and future research}

HRM in franchises is under-researched and scope for study is broad. This article focussed on questions that are pertinent, both theoretically and practically, adopting a case study design to address limitations in extant research. Case study data can be rich and descriptive, but generalisability may be limited (Yin, 2009). For instance, the Australian emphasis on policing and regulating employment practices could mean international studies yield different results. With reduced regulation or government monitoring of employment practice, franchisor emphasis on standardisation of HRM may be further restricted, or alternately, increased to address needs of franchisees not met through a government administered framework. These findings may well apply to the Australian retail franchise sector, however HRM could play out differently in systems with a more professional labour force, or where the number of unit employees is far smaller or greater than in these three cases. Variation in governance structure - heavily corporatised systems or majority multi-unit ownership - would also introduce another layer of complexity not explored in this article.

In sum, a multi-industry, multinational large scale research design, incorporating a range of governance structures, would be optimal in determining alignment in different scenarios and for identifying performance outcomes associated with variations in alignment. Investigation of relationship value using a rigorous and systematic approach could further enhance our understanding of how this concept can influence franchisee performance, in HRM and otherwise.

\section{Conclusions}


As franchising reaches maturity in Australia and the US, its effect is only just beginning to be experienced in developing nations. Despite success of the franchise model internationally, understanding of HRM system design and implementation remains surprisingly incomplete. There are enormous benefits, costs and risks associated with corporate HRM decisions, and this article extends the scope to acknowledge the influence and importance of franchisee expectations, responses, and behaviours. A 'best practice' approach to HRM in franchises would be a fitting conclusion, however the very nature of the franchise relationship and misaligned interests means what is best for one party is not necessarily best for the other. Characteristics of the organisation and industry, combined with differences in the skills and experiences of franchisees, are factors that further complicate the development of an ideal franchise HRM system. As is often the case in research on people management, context is complex but critical, and it is this nuance pertaining to HRM in franchises which is so interesting and integral for progressing scholarly knowledge. 


\section{Tables, figures and appendices}

Table 1. Franchise system and interview details

Table 2. Franchisor involvement in HRM

Figure 1. Franchisor-determined core and peripheral activities

Figure 2. Core-periphery model of HRM alignment in the franchise relationship

Figure 3. Strong core-periphery alignment at Cappuccino

Figure 4. Weak core-periphery alignment at Short Black and Cafe Latte

Figure 5. Franchisee HRM response matrix

Appendix 1. Interviewee role titles 


\section{Reference List}

Baucus, D, Baucus, M, \& Human, S. (1996). 'Consensus in franchise organizations: A cooperative arrangement among entrepreneurs', Journal of Business Venturing, 11: 5, 359-378.

Boxall, P. (2012). 'High-performance work systems: what, why, how and for whom?', Asia Pacific Journal of Human Resources, 50: 2, 169-186.

Brand, M, \& Croonen, E. (2010). 'Franchised and small, the most beautiful of all: HRM and performance in plural systems', Journal of Small Business Management, 48: 4, 605626.

Cassell, C. (2009). 'Interviews in Organisational Research', in D Buchanan \& A Bryman (eds), The Sage Handbook of Organisational Research Methods, London: Sage.

Castrogiovanni, G, \& Kidwell, RE. (2010). 'Human resource management practices affecting unit managers in franchise networks', Human Resource Management, 49: 2, 225-239.

Cochet, O, Dormann, J, \& Ehrmann, T. (2008). 'Capitalizing on franchisee autonomy: Relational forms of governance as controls in idiosyncratic franchise dyads', Journal of Small Business Management, 46: 1, 50-72.

Cox, J, \& Mason, C. (2007). 'Standardisation versus adaptation: Geographical pressures to deviate from franchise formats', The Service Industries Journal, 27: 8, 1053-1072.

Dant, RP, \& Nasr, NI. (1998). 'Control techniques and upward flow of information in franchising in distant markets: Conceptualization and preliminary evidence', Journal of Business Venturing, 13: 1, 3-28.

Davies, MA, Lassar, W, Manolis, C, Prince, M, \& Winsor, RD. (2011). 'A model of trust and compliance in franchise relationships', Journal of Business Venturing, 26: 3, 321-340.

Denzin, N, \& Lincoln, Y. (2000). Handbook of Qualitative Research, Thousand Oaks: Sage.

Doherty, AM. (2007). 'The internationalization of retailing: Factors influencing the choice of franchising as a market entry strategy', International Journal of Service Industry Management, 18: 2, 184-205.

Eisenhardt, KM. (1989). 'Building theories from case study research', Academy of Management Review, 14: 4, 532-550.

Felstead, A. (1991). 'The social organisation of the franchise: A case of controlled selfemployment', Work, Employment and Society, 5: 1, 37-57.

Frazer, L, Weaven, S, \& Grace, A. (2014). 'Franchising Australia 2014', The Franchise Council of Australia, Asia-Pacific Centre for Franchising Excellence, Griffith University.

Gorovaia, N, \& Windsperger, J. (2013). 'Determinants of knowledge transfer strategy in franchising: integrating knowledge-based and relational governance perspectives', Service Industries Journal, 33: 12, 1113-1134.

Grünhagen, M, Wollan, ML, Dada, OL, \& Watson, A. (2014). 'The moderating influence of HR operational autonomy on the entrepreneurial orientation-performance link in franchise systems', International Entrepreneurship and Management Journal, 10: 4 827-844.

Harmon, TR, \& Griffiths, MA. (2008). 'Franchisee perceived relationship value', Journal of Business \& Industrial Marketing, 23: 4, 256-263.

International Franchise Association. (2015). 'Franchise Business Economic Outlook Report for 2015', IHS Economics, http://www.franchise.org/research.

Kaufmann, P, \& Eroglu, S. (1998). 'Standardization and adaptation in business format franchising', Journal of Business Venturing, 14: 1, 69-85. 
Kellner, A. (2011). 'Human Resource Management Strategy at The Coffee Club Franchise', in T Dundon \& A Wilkinson (eds), Case Studies in People Management, Strategy and Innovation, Sydney: Tilde University Press.

Kellner, A, Peetz, D, Townsend, K, \& Wilkinson, A. (2015). 'We are very focused on the muffins': Regulation of and compliance with industrial relations in franchises', Journal of Industrial Relations, 58: 1, 25-45.

Kellner, A, Townsend, K, Wilkinson, A, \& Peetz, D. (2014). 'Decaf or double shot? The strength of franchisor control over HRM in coffee franchises', Human Resource Management Journal, 24: 3, 323-338.

Kreiner, G, Hollensbe, E, \& Sheep, M. (2009). 'Balancing borders and bridges: Negotiating the work-home interface via boundary work tactics', Academy of Management Journal, 52: 4, 704-730.

Liberal Party of Australia. (2016). 'The Coalition's Policy to Protect Vulnerable Workers', https://www.liberal.org.au/coalitions-policy-protect-vulnerable-workers, Canberra: Australian Federal Government.

Nickerson, JA, \& Silverman, BS. (2003). 'Why firms want to organize efficiently and what keeps them from doing so: Inappropriate governance, performance, and adaptation in a deregulated industry', Administrative science quarterly, 48: 3, 433-465.

Paik, Y, \& Choi, D. (2007). 'Control, autonomy and collaboration in the fastfood industry: A comparative study between domestic and international franchising', International Small Business Journal, 25: 5, 539-562.

Patton, M. (2002). Qualitative Research and Evaluation Methods (3rd Edition), Thousand Oaks: Sage.

Phan, P, Butler, J, \& Lee, S. (1996). 'Crossing mother: Entrepreneur-franchisees' attempts to reduce franchisor influence', Journal of Business Venturing, 11: 5, 379-402.

Pizanti, I, \& Lerner, M. (2003). 'Examining control and autonomy in the franchisor-franchisee relationship', International Small Business Journal, 21: 2, 131-159.

Quinn, B, \& Doherty, AM. (2000). 'Power and control in international retail franchising: Evidence from theory and practive', International Marketing Review, 17: 4, 354-372.

Sampson, RC. (2004). 'The cost of misaligned governance in R\&D alliances', Journal of Law, Economics, and Organization, 20: 2, 484-526.

Silverman, BS, Nickerson, JA, \& Freeman, J. (1997). 'Profitability, transactional alignment, and organizational mortality in the US trucking industry', Strategic Management Journal, 18: Summer, 31-52.

Truss, C. (2004). 'Who's in the driving seat? Managing human resources in a franchise firm', Human Resource Management Journal, 14: 4, 57-75.

Yin, RK. (2009). Case Study Research: Design and Methods (4th Edition), London: Sage. 